\title{
Evaluation of Pain Pressure Threshold and Widespread Pain in Chronic Low Back Pain
}

\section{Kronik Bel Ağrısında Basınç Ağrı Eșiği ve Yaygın Ağrının Değerlendirilmesi}

\author{
Şenay ÖZDOLAP'1, Selda SARIKAYA', Fürüzan KÖKTÜRK² \\ ${ }^{1}$ Department of Physical Medicine and Rehabilitation, Bülent Ecevit University Faculty of Medicine, Zonguldak, Turkey \\ ${ }^{2}$ Department of Biostatistics, Bülent Ecevit University Faculty of Medicine, Zonguldak, Turkey
}

\begin{abstract}
Objective: The purpose of this study was to determine differences in pain pressure threshold (PPT) values between patients with chronic low back pain (CLPB) and healthy people and to also evaluate widespread pain sensitivity by testing PPT in different sites of patients with CLBP. Material and Methods: Seventy subjects with CLBP and 62 healthy controls were included in the study. PPT values were evaluated for a total of 34 points, including 18 tender points defined for fibromyalgia syndrome by the American College of Rheumatology, 12 points for testing of sciatic valleix, and 4 lumbar paravertebral points, in both groups. An electronic pressure algometer was used to measure PPT with a stimulation surface area of $1 \mathrm{~cm}^{2}$.

Results: A significantly lower mean PPT was determined for all test sites in the patients with CLBP compared with healthy controls $(p=0.001)$.

Conclusion: The study showed that patients with CLBP have significantly lower PPT values at every individual site compared with healthy controls. This result suggests that widespread pain should be taken into account in the evaluation of patients with CLBP.

Key Words: Chronic low back pain, pressure algometer, pain pressure threshold
\end{abstract}

Özet

Amaç: Bu çalışmanın amacı, kronik bel ağrısı olan hastalar ve sağlıklı bireyler arasında basınç ağrı eşiği değerleri açısından farkı belirlemek, aynı zamanda kronik bel ağrısı olan hastalarda farklı anatomik bölgelerde basınç ağıı eşiği test edilerek yaygın ağrıyı incelemektir.

Gereç ve Yöntemler: Kronik bel ağrılı 70 hasta ve 62 sağlıklı kontrol çalışmaya dahil edildi. Basınç ağrı eşiği, her iki grupta, Amerikan Romatizma Cemiyeti tarafından belirlenen 18 fibromiyalji hassas noktası, 12 siyatik valleks noktası ve 4 lomber paravertebral nokta olmak üzere toplam 34 noktada değerlendirildi. Basınç ağrı eşiği ölçümleri, yüzey alanı $1 \mathrm{~cm}^{2}$ olan elektronik basınç algometre cihazı ile yapıldı.

Bulgular: Kronik bel ağrılı hastalarda tüm noktalarda ortalama basınç ağrı eşiği, sağlıklı kontrollere göre anlamlı düzeyde düşük bulundu $(p=0,001)$. Sonuç: Bu çalışma, kronik bel ağrılı hastalarda sağlıklı kontrollere göre tüm vücutta basınç ağrı eşiğinin düşük olduğunu gösterdi. Bu sonuç, kronik bel ağrısı olan hastaların değerlendirilmesinde yaygın ağrının göz önünde bulundurulması gerektiğini düşündürür niteliktedir.

Anahtar Kelimeler: Kronik bel ağrısı, basınç algometresi, ağrı basınç eşiği

\section{Introduction}

Chronic low back pain (CLBP) is one of the most common musculoskeletal disorders, which leads to disability and thus creates an economic burden in industrialized countries (1). Unfortunately, the techniques available to understand the underlying mechanism and severity have remained very limited. Furthermore, few patients with back pain have well-known structural or mechanical causes, and the correlation between the degree of structural or mechanical abnormality and the resultant pain, even among patients with structural abnormalities of the spinous elements, has not been well established (2-5). Detailed physical examination, including evaluation of pain sensitivity, is necessary to define the clinical picture of a patient with CLBP. Although pain sensitivity or, in other words, tenderness was accepted as a useful finding for evaluation of musculoskeletal disorders, it is not generally used in the assessment of patients with

Address for Corespondance / Yazışma Adresi: Şenay Özdolap MD, Department of Physical Medicine and Rehabilitation, Bülent Ecevit University Faculty of Medicine, Zonguldak, Turkey. Phone: +90 3722612450 E-mail: senayozd@yahoo.com 
CLBP. As the interpretation of tenderness with the traditional method (ie, manual palpation) is confusing and insufficient, an algometer was developed and used to determine the pressure pain sensitivity precisely. This method, algometry, is proven to be a reliable method by several studies $(6,7)$.

Pain sensitivity varies in the general population. While some patients exhibit a high pain threshold, others have a low pain threshold (8-10). The central neuron mechanisms and peripheral mechanisms have been the focus of studies to identify the neural mechanism underlying the development of hypersensitivity in tissues, such as muscle tenderness (11). The response properties of the dorsal horn and brain stem neurons change due to continuous nociceptive input (12), altering the normal processing of nociceptive and non-nociceptive information. As a result, pain threshold may be lowered. Although several studies have suggested the involvement of central mechanisms in lowering pain pressure threshold (PPT) in musculoskeletal disorders, such as CLBP (13-15), the way by which the neuronal mechanisms cause widespread pain and hypersensitivity in patients with CLBP remains controversial. Widespread pain is commonly defined as pain presenting on both sides of the body, above and below the waist, and also involving the axial skeleton (16). Population-based studies suggest that chronic widespread pain is seen in $5 \%$ to $15 \%$ of the population (9). A number of studies reported that widespread pain may occur among patients with $\operatorname{CLBP}(4,15)$, whereas other studies also suggest that widespread pain may be a result of CLBP (17). Many factors, including demographic $(18,19)$, psychosocial $(20,21)$, environmental (22), and structural abnormalities $(5,23)$, have been investigated to better understand the mechanism of hypersensitivity and widespread pain in patients with CLBP.

The primary purpose of this study was to determine differences in pain pressure threshold between patients with CLPB and healthy people, using a number of points in several regions anatomically related or unrelated to the lumbar spine. The study also aimed to show low PPT values and widespread pain sensitivity by testing pain pressure threshold in anatomically unrelated sites of patients with CLBP.

\section{Material and Methods}

Seventy patients (44 female, 26 male) with CLBP and 62 healthy control subjects ( 33 female, 29 male) without a history of low back pain were enrolled in the study. The inclusion criteria for the CLBP group were low back pain for more than 6 months without pain radiation to the buttock and lower extremity and without any neurological sings. Demographic characteristics (gender, age, history of LBP) were recorded. All the subjects were evaluated through a routine neurological and physical examination. Additional inclusion criteria for both groups were age between 20 and 60 years; no spine surgery in the previous 6 months; no history of concurrent disorders causing low back pain; and no use of opioid analgesics, antidepressants, or anticonvulsant medications within the last 3 weeks prior to testing. The subjects reported no use of non-steroidal anti-inflammatory drugs within 24 hours before testing. Also, subjects who were diagnosed with fibromyalgia syndrome according to ACR criteria were excluded.
For all the subjects, 18 tender points (TP) defined by the American College of Rheumatology for fibromyalgia syndrome (16), 12 points for the sciatic valleix (bilateral middle point of gluteus maximus, middle point of the gluteal sulcus, middle and posterior point of thigh, popliteal fossa, middle and posterior point of cruris, middle point of Achilles tendon), and 4 lumbar paravertebral points (bilateral $2 \mathrm{~cm}$ lateral to the $\mathrm{L} 2$ and $L 4$ spinous processes) were evaluated. An electronic pressure algometer (Algometer commander, JTech Medical, 4314 ZEVEX Park Line; Salt Lake City, UT 84123) was used to measure pressure pain threshold (PPT) with a stimulation surface area of $1 \mathrm{~cm}^{2}$. Three consecutive measurements were performed at each site, with 10 seconds of recovery time allowed between repeated applications. During the algometric measurements, the subjects were asked to say "yes" when the pain was experienced. The amount of pressure-causing pain was recorded as PPT in kg/ $\mathrm{cm}^{2}$. The subjects were fully informed about the investigation and how to do the measurements. All PPT measurements were made by the same investigator (SO). The investigator who performed PPT measurements was blinded to the patients' clinical information and examination. The subjects were required to lie down in a prone position for the lumbar and sciatic valleix measurements. For fibromyalgia tender point measurements, the subjects were sitting in a chair. The first fibromyalgia tender point measurements were performed; then, PPT measurements were carried out on the lumbar and sciatic valleix points.

The sum of PPT of 18 points for tender points, 12 points for the sciatic valleix, and 4 points for the lumbar paravertebrae were calculated separately as final scores in $\mathrm{kg} / \mathrm{cm}^{2}$.

Visual analog scale (VAS) was used to measure the low back pain intensity. The $10-\mathrm{cm}$ scale was marked with " 0 " for no pain and "10" for worst imaginable pain. The patients with CLBP were asked to mark their pain intensity on the scale at the moment of the evaluation.

The study protocol was approved by the ethics reviewing committee guidelines of our university, and written informed consent was obtained from each subject. All the subjects were volunteers who were not compensated for their participation.

\section{Statistical Analysis}

Statistical analysis was performed with Statistical Package for the Social Sciences (SPSS) 18.0 software (SPSS, Inc., Chicago, IL, USA). Continuous variables were expressed as mean \pm standard error of mean or median (minimum-maximum), and categorical variables were expressed as frequency and percent. Continuous variables were compared with the independent sample t test or Mann-Whitney $U$ test, and categorical variables were compared using Pearson chi-square test. A p value of less than 0.05 was considered statistically significant for all tests. Optimal sample size was determined by power analysis with G power. Sample size was calculated for a two-sided test with a significance level of $5 \%$ and power of $80 \%$.

\section{Results}

The mean age of the CLBP group was 37.6 years $(S D=10.1)$, and the mean age of the healthy controls was 34.6 years 


\begin{tabular}{|c|c|c|c|}
\hline Test sites & $\begin{array}{l}\text { CLBP Group } \\
(n=70)\end{array}$ & $\begin{array}{c}\text { Control Group } \\
(n=62)\end{array}$ & $\begin{array}{c}p \\
\text { value }\end{array}$ \\
\hline Fibromyalgia tender points & $87.2 \pm 29.5$ & $105.0 \pm 31.6$ & 0.001 \\
\hline 12 sciatic valleix points & $78.5 \pm 25.8$ & $93.4 \pm 26.1$ & 0.001 \\
\hline 4 lumbar paravertebral points & $\begin{array}{c}18.8 \\
(6.03-62.40)\end{array}$ & $\begin{array}{c}28.7 \\
(6.6-46.2)\end{array}$ & $<0.001$ \\
\hline
\end{tabular}

$(S D=9.6)$. There were no statistically significant differences between the mean age of the two groups $(p=0.090)$. The mean duration of pain in the CLBP group was 5.8 years $(S D=5.4)$, and the mean visual analog scale was $5.4(\mathrm{SD}=1.9)$.

The mean PPT values tended to be significantly lower for every site in the CLBP group than in the control group $(p=0.001)$. The mean and standard deviation of PPT values obtained from all test sites have been presented in Table 1 below.

Women were found to have significantly lower PPT in the 18 fibromyalgia tender and 12 sciatic valleix points than men in both the patient group $(p<0.001)$ and control group $(p=0.001)$. There were no statistically significant differences between men and women for the 4 lumbar paravertebral points in the patient and control groups ( $p=0.098, p=0.097$ respectively).

\section{Discussion}

Mechanical stimuli have been used to evaluate the sensitization of myofascial tissues, such as tender points, work-related myalgia, and fibromyalgia. Assessment of pain sensitivity with manual palpation is a simple technique but is difficult to standardize and shows moderate sensitivity. Additionally, the reliability of manual palpation depends on the application technique of the examiner (24). On the other hand, the use of a pressure algometry technique to assess the sensitization is increasing because of its proven efficiency and reliability in muscle pain syndromes $(6,7)$. Pressure algometry enables the application of a known force to skin and underlying myofascial tissues. The gradually increasing force is applied over the target area until patients specify pain rather than pressure. Also, this device has been used in different areas of the body, such as the patellar tendon and abdominal wall, to assess pain pressure threshold $(25,26)$.

Although many researchers have studied PPT in patients with low back pain (LBP), the mechanism of the widespread low level of PPT has not been clearly defined. Several studies investigated PPT at sites anatomically related and unrelated to the lumbar spine $(1,4)$. Lower PPT values were determined in patients with LBP, even at anatomically unrelated sites $(1,4,27)$. In addition, the mechanism of pain pressure threshold was studied at various anatomical sites in patients with chronic musculoskeletal conditions, such as $\operatorname{LBP}(1,4,11,27)$, fibromyalgia (28), strain injuries (29), rheumatoid arthritis (30), and osteoarthritis (31). Central sensitization may be determined using a number of palpable trigger points. Bajaj et al. (32) found a significantly higher number of trigger points in the lower limb muscles in patients with knee osteoarthritis than in the healthy controls.
A number of studies have shown central sensitization to be responsible for sensory threshold changes and widespread tenderness, as well as peripheral sensitization $(13,14,33)$. Tissue damage stimulates the release of numerous inflammatory mediators from neurons and immune cells (34), resulting in activation of nociceptors in the injury area and nociceptor hypersensitivity. Increased nociceptor sensitivity is expressed by spontaneous firing, enlargement of the neuronal receptive field, and decreased firing threshold $(35,36)$, which is known as the peripheral sensitization-an initiative for pain. Effective changes in tissue sensitivity may develop immediately after injury and the resultant pain because of neurobiological influences $(14,37)$. Then, they may be followed by pain in unrelated sites and persistent exaggerated pain outside of the neuro-anatomical sensory distribution of the primary lesion. The change in threshold may be responsible for continuous pain rather than continuing tissue injury (38). On the other hand, people with persistent pain may experience secondary hypersensitivity at unrelated body sites outside of the injured tissue. In such cases, local nociceptive excitation and peripheral sensitization may coexist with a state of secondary hyperalgesia, leading to diffuse pain experience. This condition, known as central sensitization, contributes to diffuse hypersensitivity in regions beyond the damaged tissue (39).

The present study investigated PPT in a number of different sites to determine pain expected areas and pain-free control areas, such as tender points in upper sites of the body. The results of the study showed that patients with CLBP (CLBP group) had lower PPT values at every individual site compared with the healthy controls. All patients with CLBP showed significant generalized hyperalgesia when compared with the control group, which is compatible with the results of earlier studies showing low PPT values in chronic pain patients $(1,4,28,32)$.

The findings of the study may be attributed to the development of central sensitization and maladaptive pain processing involving widespread hypersensitivity. The bombardment of neurons in the dorsal horn by the primary afferent system stimulates $\mathrm{N}$-methyl-D-aspartate receptors and overwhelms pain control centers (40). The resultant neuronal plasticity in the dorsal horn and supraspinal regions contributes to spontaneous pain (38). Previous sub-threshold inputs from the somatosensory system begin to generate potentials from the dorsal horn to the central nerve system. Central sensitization is reinforced by the activation of low-threshold small-diameter primary afferents, thus allowing low-intensity stimulation to be perceived as pain and producing long-term changes in spinal neurons (41). Woolf et al. (42) have suggested three pathological mechanisms that might contribute to central sensitization: increased excitability, decreased inhibition, and structural reorganization of CNS. The combination of excitation and disinhibition causes persistent pain after a primary injury. People with CLBP had enhanced reactivity and reorganization of the somatosensory cortex with a positive relationship between cortical reactivity and chronicity (43). Giesbrecth et al. (1) suggested that biopsychosocial influences may have contributed to the differences in pain sensation between people with CLBP and people without pain. In the study of Peters et al. (44), those with CLBP were less sensitive to 
pressure stimuli than those without CLBP. Very few points involving the index finger and right ankle were tested. Their findings contradict our findings. Nevertheless, in our study, local and distant points to the lumbar spine that were reliable were selected as test sites. Johansen et al. found lower PPT in the neck, shoulder, and tibial regions of subjects with whiplash-associated disorders (14). The results of the studies by Johansen and Bajaj are supportive of our findings $(14,32)$. Our findings suggest that subjects with CLBP show significant global hypersensitivity compared with subjects without pain. Kasch et al. (29) have reported contrary results by measuring PPT in patients with acute whiplash and acute ankle distortion injury in the head and neck regions. The patients with acute whiplash injury had lower PPT at the head and neck sites up to 3 months, but there were no significant differences in PPT values in the 6 months following injury. They held peripheral sensitization responsible for hypersensitivity in the head and neck sites but reported no hypersensitivity in unrelated sites.

\section{Conclusion}

In conclusion, the current study points out that pain pressure thresholds measured in several regions anatomically related or unrelated to the lumbar spine in patients with chronic low back pain are significantly lower than those in healthy control subjects. It could be of great value to evaluate the presence of widespread pain in patients with chronic low back pain.

Ethics Committee Approval: Ethics committee approval was received for this study from the ethics committee of Bülent Ecevit University Faculty of Medicine.

Informed Consent: Written informed consent was obtained from patients who participated in this study.

Peer-review: Externally peer-reviewed.

Author Contributions: Concept - Ş.Ö.; Design - Ş.Ö., S.S.; Supervision - S.S.; Materials - Ş.Ö., S.S.; Data Collection and/or Processing - Ş.Ö., S.S.; Analysis and/or Interpretation - F.K., Ş.Ö., S.S.; Literature Review - Ş.Ö.; Writer - Ş.Ö.; Critical Review - S.S.

Conflict of Interest: No conflict of interest was declared by the authors.

Financial Disclosure: The authors declared that this study has received no financial support.

Etik Komite Onayı: Bu çalışma için etik komite onayı Bülent Ecevit Üniversitesi Tıp Fakültesi'nden alınmıştır.

Hasta Onamı: Yazılı hasta onamı bu çalışmaya katılan hastalardan alınmıştır.

\section{Hakem değerlendirmesi: Dış bağımsız.}

Yazar Katkıları: Fikir - Ş.Ö.; Tasarım - Ş.Ö., S.S.; Denetleme - S.S.; Malzemeler - S..Ö., S.S.; Veri toplanması ve/veya işlemesi Ş.Ö., S.S.; Analiz ve/veya yorum - F.K., Ş.Ö., S.S.; Literatür taraması - Ş.Ö.; Yazıyı yazan - Ş.Ö.; Eleştirel Inceleme - S.S.
Çıkar Çatışması: Yazarlar çıkar çatı̧̧ması bildirmemişlerdir.

Finansal Destek: Yazarlar bu çalışma için finansal destek almadıklarını beyan etmişlerdir.

\section{References}

1. Giesbrecht RJ, Battie MC. A comparison of pressure pain detection thresholds in people with chronic low back pain and volunteers without pain. Phys Ther 2005;85:1085-92.

2. Boden SD, McCowin PR, Davis DO, Dina TS, Mark AS, Wiesel S. Abnormal magnetic-resonance scans of the cervical spine in asymptomatic subjects. A prospective investigation. J Bone Joint Surg Am 1990;72:1178-84.

3. Boos N, Lander PH. Clinical efficacy of imaging modalities in the diagnosis of low-back pain disorders. Eur Spine J 1996;5:2-22. [CrossRef]

4. Clauw DJ, Williams D, Lauerman W, Dahlman M, Aslami A, Nachemson $\mathrm{AL}$, et al. Pain sensitivity as a correlate of clinical status in individuals with chronic low back pain. Spine (Phila Pa 1976) 1999;24:2035-41. [CrossRef]

5. Jensen MC, Brant-Zawadzki MN, Obuchowski N, Modic MT, Malkasian D, Ross JS. Magnetic resonance imaging of the lumbar spine in people without back pain. N Engl J Med 1994;331:69-73. [CrossRef]

6. Kosek E, Ekholm J, Hansson P. Pressure pain thresholds in different tissues in one body region. The influence of skin sensitivity in pressure algometry. Scand J Rehabil Med 1999;31:89-93. [CrossRef]

7. Pöntinen P. Reliability, validity, reproducibility of algometry in diagnosis of active and latent tender spots and trigger points. J Musculoskelet Pain 1998;6:61-71. [CrossRef]

8. Croft P, Schollum J, Silman A. Population study of tender point counts and pain as evidence of fibromyalgia. BMJ 1994;309:696-9. [CrossRef]

9. Wolfe F, Ross K, Anderson J, Russell IJ. Aspects of fibromyalgia in the general population: sex, pain threshold, and fibromyalgia symptoms. J Rheumatol 1995;22:151-6.

10. Wolfe F, Ross K, Anderson J, Russell IJ, Hebert L. The prevalence and characteristics of fibromyalgia in the general population. Arthritis Rheum 1995;38:19-28. [CrossRef]

11. Hirayama J, Yamagata M, Ogata S, Shimizu K, Ikeda Y, Takahashi K. Relationship between low-back pain, muscle spasm and pressure pain thresholds in patients with lumbar disc herniation. Eur Spine J 2006;15:41-7. [CrossRef]

12. Woolf CJ, Thompson SW, King AE. Prolonged primary afferent induced alterations in dorsal horn neurones, an intracellular analysis in vivo and in vitro. J Physiol (Paris) 1988;83:255-66.

13. Giesecke T, Gracely RH, Grant MA, Nachemson A, Petzke F, Williams DA, et al. Evidence of augmented central pain processing in idiopathic chronic low back pain. Arthritis Rheum 2004;50:613-23. [CrossRef]

14. Koelbaek Johansen M, Graven-Nielsen T, Schou Olesen A, ArendtNielsen L. Generalised muscular hyperalgesia in chronic whiplash syndrome. Pain 1999;83:229-34. [CrossRef]

15. Nordeman L, Gunnarsson R, Mannerkorpi K. Prevalence and characteristics of widespread pain in female primary health care patients with chronic low back pain. Clin J Pain 2012;28:65-72. [CrossRef]

16. Wolfe F, Smythe HA, Yunus MB, Bennett RM, Bombardier C, Goldenberg DL, et al. The American College of Rheumatology 1990 Criteria for the Classification of Fibromyalgia. Report of the Multicenter Criteria Committee. Arthritis Rheum 1990;33:160-72. [CrossRef]

17. Lapossy E, Maleitzke R, Hrycaj P, Mennet W, Muller W. The frequency of transition of chronic low back pain to fibromyalgia. Scand J Rheumatol 1995;24:29-33. [CrossRef] 
18. Boos N, Rieder R, Schade V, Spratt KF, Semmer N, Aebi M. 1995 Volvo Award in clinical sciences. The diagnostic accuracy of magnetic resonance imaging, work perception, and psychosocial factors in identifying symptomatic disc herniations. Spine (Phila Pa 1976) 1995;20:2613-25. [CrossRef]

19. Burton AK, Tillotson KM. Prediction of the clinical course of lowback trouble using multivariable models. Spine (Phila Pa 1976) 1991;16:7-14. [CrossRef]

20. Bigos SJ, Battie MC, Spengler DM, Fisher LD, Fordyce WE, Hansson $\mathrm{TH}$, et al. A prospective study of work perceptions and psychosocial factors affecting the report of back injury. Spine (Phila Pa 1976) 1991;16:1-6. [CrossRef]

21. Burton AK, Tillotson KM, Main C], Hollis S. Psychosocial predictors of outcome in acute and subchronic low back trouble. Spine (Phila Pa 1976) 1995;20:722-8. [CrossRef]

22. Greenough CG, Fraser RD. Comparison of eight psychometric instruments in unselected patients with back pain. Spine (Phila $\mathrm{Pa}$ 1976) 1991;16:1068-74. [CrossRef]

23. Cooper RG, Freemont AJ, Hoyland JA, Jenkins JP, West CG, Illingworth $\mathrm{KJ}$, et al. Herniated intervertebral disc-associated periradicular fibrosis and vascular abnormalities occur without inflammatory cell infiltration. Spine (Phila Pa 1976) 1995;20:591-8. [CrossRef]

24. Chesterton LS, Sim J, Wright CC, Foster NE. Interrater reliability of algometry in measuring pressure pain thresholds in healthy humans, using multiple raters. Clin J Pain 2007;23:760-6. [CrossRef]

25. Montenegro ML, Braz CA, Mateus-Vasconcelos EL, Rosa-e-Silva JC, Candido-dos-Reis FJ, Nogueira AA, et al. Pain pressure threshold algometry of the abdominal wall in healthy women. Braz J Med Biol Res 2012;45:578-82. [CrossRef]

26. van Wilgen $P$, van der Noord R, Zwerver J. Feasibility and reliability of pain pressure threshold measurements in patellar tendinopathy. J Sci Med Sport 2011;14:477-81. [CrossRef]

27. Farasyn A, Meeusen R. The influence of non-specific low back pain on pressure pain thresholds and disability. Eur J Pain 2005;9:375-81. [CrossRef]

28. Granges G, Littlejohn G. Pressure pain threshold in pain-free subjects, in patients with chronic regional pain syndromes, and in patients with fibromyalgia syndrome. Arthritis Rheum 1993;36:642-6. [CrossRef]

29. Kasch H, Stengaard-Pedersen K, Arendt-Nielsen L, Staehelin Jensen T. Pain thresholds and tenderness in neck and head following acute whiplash injury: a prospective study. Cephalalgia 2001;21:189-97. [CrossRef]

30. Leffler AS, Kosek E, Lerndal T, Nordmark B, Hansson P. Somatosensory perception and function of diffuse noxious inhibitory controls (DNIC) in patients suffering from rheumatoid arthritis. Eur J Pain 2002;6:161-76. [CrossRef]

31. Arendt-Nielsen L, Nie H, Laursen MB, Laursen BS, Madeleine P, Simonsen $\mathrm{OH}$, et al. Sensitization in patients with painful knee osteoarthritis. Pain 2010;149:573-81. [CrossRef]

32. Bajaj P, Bajaj P, Graven-Nielsen T, Arendt-Nielsen L. Osteoarthritis and its association with muscle hyperalgesia: an experimental controlled study. Pain 2001;93:107-14. [CrossRef]

33. Staud R. Is it all central sensitization? Role of peripheral tissue nociception in chronic musculoskeletal pain. Curr Rheumatol Rep 2010;12:448-54. [CrossRef]

34. Dray A. Peripheral mediators of pain In: Dray A, Dickenson $\mathrm{AH}$,Besson JM, eds. Handbook of experimental Pharmacology. Berlin: Springer-Verlag, 1997.pp.22-41.

35. Dray A, Urban L. New pharmacological strategies for pain relief. Annu Rev Pharmacol Toxicol 1996;36:253-80. [CrossRef]

36. Dubner R, Ren K. Endogenous mechanisms of sensory modulation. Pain 1999;6:45-53. [CrossRef]

37. Carr DB, Goudas LC. Acute pain. Lancet 1999;353:2051-8. [CrossRef]

38. Woolf C], Salter MW. Neuronal plasticity: increasing the gain in pain. Science 2000;288:1765-9. [CrossRef]

39. Woolf C]. Evidence for a central component of post-injury pain hypersensitivity. Nature 1983;306:686-8. [CrossRef]

40. Coderre TJ, Katz J, Vaccarino AL, Melzack R. Contribution of central neuroplasticity to pathological pain: review of clinical and experimental evidence. Pain 1993;52:259-85. [CrossRef]

41. Woolf C], Thompson SW. The induction and maintenance of central sensitization is dependent on $\mathrm{N}$-methyl-D-aspartic acid receptor activation; implications for the treatment of post-injury pain hypersensitivity states. Pain 1991;44:293-9. [CrossRef]

42. Woolf CJ, Doubell TP. The pathophysiology of chronic pain-increased sensitivity to low threshold A beta-fibre inputs. Curr Opin Neurobiol 1994;4:525-34. [CrossRef]

43. Flor $\mathrm{H}$, Braun $\mathrm{C}$, Elbert $\mathrm{T}$, Birbaumer $\mathrm{N}$. Extensive reorganization of primary somatosensory cortex in chronic back pain patients. Neurosci Lett 1997;224:5-8. [CrossRef]

44. Peters ML, Schmidt AJ. Differences in pain perception and sensory discrimination between chronic low back pain patients and healthy controls. J Psychosom Res 1992;36:47-53. [CrossRef] 